\title{
EVALUATION OF URGENT ESOPHAGECTOMY IN ESOPHAGEAL PERFORATION
}

\author{
Avaliação da esofagectomia de urgência na perfuração esofágica
}

José Luis Braga de AQUINO, José Gonzaga Teixeira de CAMARGO, Gustavo Nardini CECCHINO, Douglas Alexandre Rizzanti PEREIRA, Caroline Agnelli BENTO, Vânia Aparecida LEANDRO-MERHI

From the Serviço de Cirurgia Torácica do Hospital Celso Pierro da Faculdade de Medicina da Pontifícia Universidade Católica de Campinas (Department of Thoracic Surgery of the Celso Pierro Maternity and Hospital, Faculty of Medicine - Pontifícia Universidade Católica de Campinas), Campinas, SP, Brazil.
ABSTRACT - Background: Esophageal trauma is considered one of the most severe lesions of the digestive tract. There is still much controversy in choosing the best treatment for cases of esophageal perforation since that decision involves many variables. The readiness of medical care, the patient's clinical status, the local conditions of the perforated segment, and the severity of the associated injuries must be considered for the most adequate therapeutic choice. Aim: To demonstrate and to analyze the results of urgent esophagectomy in a series of patients with esophageal perforation. Methods: A retrospective study of 31 patients with confirmed esophageal perforation. Most injuries were due to endoscopic dilatation of benign esophageal disorders, which had evolved with stenosis. The diagnosis of perforation was based on clinical parameters, laboratory tests, and endoscopic images. The main surgical technique used was transmediastinal esophagectomy followed by reconstruction of the digestive tract in a second surgical procedure. Patients were evaluated for the development of systemic and local complications, especially for the dehiscence or stricture of the anastomosis of the cervical esophagus with either the stomach or the transposed colon. Results: Early postoperative evaluation showed a survival rate of $77.1 \%$ in relation to the proposed surgery, and $45 \%$ of these patients presented no further complications. The other patients had one or more complications, being pulmonary infection and anastomotic fistula the most frequent. The seven patients $(22.9 \%)$ who underwent esophageal resection 48 hours after the diagnosis died of sepsis. At medium and long-term assessments, most patients reported a good quality of life and full satisfaction regarding the surgery outcomes. Conclusions: Despite the morbidity, emergency esophagectomy has its validity, especially in well indicated cases of esophageal perforation subsequent to endoscopic dilation for benign strictures.
HEADINGS - Thoracic surgery. Esophagectomy. Trauma.
RESUMO: Racional: O trauma de esôfago é considerado uma das lesões mais graves do trato digestivo. O tratamento de escolha para casos de perfuração esofágica ainda é controverso, visto que esta decisão envolve inúmeras variáveis. As condições clínicas do paciente, as condições locais no segmento do esôfago perfurado, a gravidade das lesões associadas e o tempo de atendimento são essenciais para que a equipe cirúrgica possa instituir o tratamento adequado. Objetivo: Demonstrar e analisar os resultados da esofagectomia de urgência em uma série de pacientes com perfuração do esôfago. Método: Estudo retrospectivo incluindo 31 pacientes com confirmação diagnóstica de perfuração esofágica. A maior parte das lesões foi consequente à dilatação endoscópica de afecções benignas do esôfago que evoluíram com estenose. O diagnóstico da perfuração foi baseado em parâmetros clínicos, exames laboratoriais, radiológicos e endoscopia digestiva alta. A principal técnica cirúrgica utilizada foi a esofagectomia transmediastinal seguida da reconstrução do trânsito digestivo em um segundo tempo cirúrgico. Os pacientes foram avaliados em relação ao desenvolvimento de complicações sistêmicas e locais, notadamente deiscência e estenose da anastomose do esôfago cervical com o estômago ou cólon transposto. Resultados: A avaliação pós-operatória precoce demonstrou sobrevida de $77,1 \%$ em relação ao ato cirúrgico proposto, sendo que $45 \%$ não apresentou qualquer complicação. Os outros pacientes apresentaram uma ou mais complicações, sendo a infecção pulmonar e a fístula anastomótica as mais frequentes. Sete pacientes $(22,9 \%)$ evoluíram a óbito por quadro séptico. Tais pacientes foram submetidos à ressecção esofágica após 48 horas do diagnóstico da perfuração. Na avaliação a médio e longo prazo, a maioria dos pacientes relatou estar satisfeito com o ato cirúrgico, referindo boa qualidade de vida. Conclusões: Apesar da morbidade não desprezível, a esofagectomia de urgência tem sua validade, principalmente em casos de perfuração esofágica consequentes à dilatação endoscópica para estenoses benignas.
DESCRTORES - Cirurgia torácica Esofagectomia. Trauma.
$\mathrm{D}$ espite the great diagnostic advances, esophageal perforation is still one of the most severe lesions of the digestive tract, both by the significant morbidity and its high mortality, reaching up to $67 \%$ in some studies ${ }^{4,10,16,22,26}$. Contributing factors include the peculiar anatomy and location of the esophagus. In cases of perforation, the absence of a serous membrane and the sparse areolar tissue allow easy access for bacteria and digestive enzymes to the mediastinum, predisposing to the development of serious complications such as mediastinitis, empyema and sepsis $^{2,5,14}$. 
Technological advances associated with the increased number of indications of upper digestive endoscopy have increased the risk of esophageal perforation ${ }^{10,12,22}$. However, the low incidence of this condition and its often atypical clinical presentation imposes a great challenge, favoring a delay in diagnosis and treatment in over $50 \%$ of cases ${ }^{10,14,26}$.

The major predictor of survival in cases of esophageal perforation is the time interval between esophageal injury and treatment initiation. However, the etiology of the perforation, the location of the lesion, the presence of previous esophageal disease and the experience of the multidisciplinary team are also greatly relevant ${ }^{3,4,9,18}$. There is still divergence concerning the best treatment option, ranging from conservative medical therapy to surgical and primary repair, to esophageal exclusion, drainage or even esophageal resection ${ }^{1,4,10,23,26}$

Esophagectomy is still controversial in cases of esophageal perforation. It is performed as the treatment choice in $7 \%$ to $58 \%$ at most, mainly due to the complexity of the surgery, especially in urgent situations, which may result in higher rates of complication 1,2,4,10,12-14,22,26.

Recently, in order to optimize the selection of patients eligible for resection after esophageal perforation, some authors have indicated this procedure mainly when there is obstructive esophageal disease, extensive injury of the esophageal lumen with a narrowing of $50 \%$ or more with primary repair, late lesion ( $>24 \mathrm{~h}$ ) associated with severe mediastinitis or pleural contamination, or when the viability of the esophagus is uncertain ${ }^{1,14,20,24}$.

The scarcity of information concerning the appropriate indication of urgent esophagectomy in cases of esophageal perforation motivated this study, which aims to demonstrate the authors' experience with this procedure through a retrospective analysis of the results of urgent esophagectomy in patients with esophageal perforation with regard to local and systemic complications.

\section{METHOD}

Between January of 1991 and July of 2013, the Thoracic Surgery Department of the Celso Pierro Maternity and Hospital at the Faculty of Medicine PUC - Campinas, Campinas, SP, Brazil, admitted 31 patients for esophageal perforation with indication of urgent esophagectomy. The population was composed of 23 men $(74,1 \%)$ and 8 women, with ages between 21 and 78 years old, with a medium of 48,5 years. Every participating signed a consent form.

The patients had diagnostic confirmation of esophageal perforation by imaging and all of them had satisfying nutritional and clinical status to undergo the procedure.

\section{Surgical technique}

The surgical technique consisted of transmediastinal esophagectomy with or without right side thoracotomy and reconstruction of the digestive tract by either cervical laparotomy with gastric transposition or retrosternal transposition of the transverse colon.

\section{Postoperative evaluation}

During the postoperative period, there was great caution for early identification of possible systemic complications, notably cardiovascular, respiratory and infectious. The diagnoses were based on daily medical evaluation, as well as laboratory and imaging tests when necessary. Local complications were usually related to anastomosis dehiscence or stricture involving the cervical esophagus with the stomach or the transposed colon. Diagnostic confirmation was held through endoscopy and contrast radiography.

Patients' quality of life was assessed relating the recovery of an adequate swallowing function to the postoperative period. Symptoms of dysphagia were evaluated by differentiating their intensity and their relation to liquids, pastes or solids. The survival rate and the return to normal activities were also evaluated.

\section{RESULTS}

The etiology of the perforation occurred more frequently post endoscopic dilatation in 22 patients. The procedure had been indicated to 14 patients with megaesophagus, five with stenosing esophagitis secondary to gastroesophageal reflux, and three with caustic soda injury. The remaining patients had varied underlying causes: four of them had the event occur as a complication of a hiatal hernia surgical correction, three due to esophageal carcinoma perforation, one due to spontaneous perforation for esophageal candidiasis and one had dehiscence on esophagojejunal anastomosis after a total gastrectomy for gastric adenocarcinoma.

TABLE 1 - Etiology of esophageal perforation

\begin{tabular}{|c|c|}
\hline Etiology & $\mathbf{n}(\%)$ \\
\hline Endoscopic dilation & $22(70,9 \%)$ \\
\hline Megaesophagus & 14 \\
\hline Stenosing esophagitis & 5 \\
\hline Caustic soda Injury & 3 \\
\hline Surgery for hiatal hernia & $4(12,9 \%)$ \\
\hline Perforated esophageal carcinoma & $3(9,8 \%)$ \\
\hline Candidiasis & $1(3,2 \%)$ \\
\hline Anastomotic dehiscence & $1(3,2 \%)$ \\
\hline
\end{tabular}

Transmediastinal esophageal resection was performed without thoracotomy in 29 patients (93.5\%), according to the technique proposed by Pinotti ${ }^{21}$. The remaining two patients had the transmediastinal esophageal resection with right side thoracotomy. The reconstruction of the digestive tract by gastric transposition to the cervical region was performed in 22 patients. Two from the ones who had previously undergone gastrectomy had the same done with the transverse colon. Reconstruction had to be performed in a second procedure in 21 out of the 24 patients. The time interval until the second operation ranged from 60-126 days. The longest period occurred to one patient who underwent the esophageal resection for a local perforated carcinoma only after a few sessions of radiotherapy. The other seven patients had no reconstruction surgery since they died within the postoperative period of the esophagectomy.

An early review of the 24 surviving patients demonstrated that 11 did not have any complication (45\%). However, 13 of them had one or more complications, including digestive fistula consequent to anastomotic dehiscence in nine cases, pulmonary infection in eight, mediastinitis in four, and one patient with cardiac arrhythmia.

Considering the eight patients who developed pulmonary infection, five had good outcome with specific clinical treatment, and the remaining three evolved with pleural empyema requiring drainage guided by pleuroscopy. Only one of them needed further surgical intervention with thoracotomy for pulmonary decortication. All three patients had a good outcome as well.

The nine patients with gastrointestinal fistula secondary to anastomotic dehiscence were successfully treated conservatively, along with enteral nutritional support by jejunostomy. All cases had spontaneous closure of the fistula between the $15-25^{\text {th }}$ postoperative days. Six of these patients had anastomotic stricture between the $43^{\text {rd }}$ and the $62^{\text {nd }}$ days, managed with a few sessions of endoscopic dilatation.

The only patient with cardiac arrhythmia had good results with specific clinical treatment considering a known personal 
history of Chagas heart disease. Mediastinitis occurred in four patients, which was possibly related to the delayed surgical approach of $42 \mathrm{~h}$ after perforation. Although all four patients had presented with hemodynamic instability due to sepsis, the situation was reversed after extensive mediastinal drainage by right side thoracotomy. These patients were discharged between 28 and 43 days after surgery.

The other seven patients (22.9\%) in the series evolved with death due to sepsis between the $3^{\text {rd }}$ and $18^{\text {th }}$ postoperative days. Two of them had a previous diagnosis of esophageal cancer.

Correlating the time from perforation until the beginning of the medical treatment, it was evident that the greater the time interval until surgery, the greater the morbidity of the procedure (Table 2). Notably, the seven patients who underwent esophagectomy after $48 \mathrm{~h}$ were the same who died.

TABLE 2 - Time until surgery versus morbimortality

\begin{tabular}{|c|c|c|c|}
\hline Hours & $\mathbf{n}$ & Morbidity & Mortality \\
\hline $0-12 \mathrm{~h}$ & 11 & - & - \\
\hline $12-24 \mathrm{~h}$ & 9 & $9(100,0 \%)$ & - \\
\hline $24-48 \mathrm{~h}$ & 4 & $4(100,0 \%)$ & - \\
\hline $48 \mathrm{~h}$ & 7 & $7(100,0 \%)$ & $7(100,0 \%)$ \\
\hline
\end{tabular}

The medium and long-term postoperative assessments were performed in 21 out of the 24 patients who survived the surgical procedure (87.5\%). The time varied from six months to 12 years (mean 3.5 years). Eleven of them (52.3\%) did not refer any complaint and were satisfied with the surgical procedure since they returned to their usual working activities and had the ability of swallowing any type of food rescued. Eight patients reported that despite having rescued swallowing properly, they continued to have intermittent dysphagia for solids as well as symptoms associated with reflux. This finding was justified by gastric stasis and confirmed by upper digestive endoscopy. These patients showed clinical improvement with nutritional guidance and the use of proton-pump inhibitors. Only one of them developed Barrett's esophagus in the cervical esophageal stump nine years after the procedure. This patient is still under regular clinical monitoring.

One patient who presented cicatricial stenosis for caustic pharyngitis is also being followed due to intermittent dysphagia for solids, with partial improvement after pharyngeal dilatation sessions even after two and a half years after surgery.

The remaining patient who underwenturgentesophageal resection due to perforation secondary to an esophageal squamous cell carcinoma died on the $17^{\text {th }}$ postoperative month for malignant progression.

\section{DISCUSSION}

Although Hendren \& Henderson ${ }^{15}$ successfully demonstrated the treatment of thoracic esophageal perforation by resection and immediate reconstruction in 1968, to date, this procedure is still not universally accepted, being recommended only in cases of tumor causing perforation ${ }^{11}$.

Later, Imre ${ }^{17}$ advocated esophageal resection in cases of perforation of nonmalignant origin, particularly in cases of multiple lesions or even when primary repair is difficult because of the extent of the injury.

Advances in diagnosis and treatment as well as the improvement of peri and postoperative intensive care, demystified some stereotypes related to esophagectomy. Thus, some authors began to favor this procedure in urgency situations, leading to performing rates of up to $58 \%{ }^{14,26}$. However, due to the procedure's complexity, often involving patients with significant hemodynamic changes, the indication of esophageal resection remains quite selective.
In patients with potentially obstructive stenotic lesions of the esophagus, the lumen of the organ often communicates with the mediastinum, predisposing to possibly fatal bacterial and digestive enzymes invasion. Furthermore, the fistula developed at the perforated site is usually difficult to heal since there is stasis due to obstruction of distal organs. In such cases, the advantage in carrying out the esophagectomy is to eliminate esophageal disease entirely. Based on these evidences, some authors have advocated the urgency esophagectomy for stenotic lesions with perforation during attempted endoscopic dilatation, reaching a practice rate of $50 \%$ to $85 \% 1,13,14,20,24,26$. In the present study, $70.9 \%$ of patients who underwent esophageal resection had obstructive lesions of the esophagus, either by megaesophagus secondary to reflux disease, caustic soda esophagitis or even perforation after endoscopic manipulation.

Esophagectomy has also been indicated to patients with sepsis criteria regardless of the etiology of the lesion and even with a delayed diagnosis ${ }^{1,13,14,26}$. Although this procedure represents a broad and complex surgical intervention in an urgency scenario, it seeks to eliminate the primary cause of the sepsis, most likely due to mediastinitis or pleural infection as well as the esophageal lesion or the organ itself, which is often already compromised. This approach has shown to be superior to the techniques that sever and exclude the esophagus, since such options also require a complex procedure for reconstruction, with mortality rates of 35$80 \%^{1,20,24,27}$. The same has been shown for primary suture, often held after late diagnosis, it usually does not heal properly and can lead to conditions such as gastroesophageal reflux, and mortality rates between 50 and $67 \% \%^{14,24}$

Altorjay et $\mathrm{al}^{1}$, in a retrospective review of the sepsis score proposed by Elebut \& Stoner ${ }^{8}$ in 44 patients with esophageal perforation, showed that the group of 22 patients undergoing esophagectomy had significant decreasing scores from the third postoperative day on. The 22 remaining patients were managed conservatively and their score only began to decrease on the $18^{\text {th }}$ day after surgery, resulting in a higher incidence of death from infection.

Another controversial point consists of whether the urgency esophagectomy should be performed through thoracic or transmediastinal approach. The advantage of the latter is to minimize possible pleural and pulmonary complications that occur most frequently when performing a thoracotomy. However, in cases of late and severe diagnosis of esophageal perforation with intense pleural and mediastinal contamination, the transthoracic approach is preferred since it allows more adequate drainage and washing, facilitating debridement and pulmonary decortication if necessary. This was demonstrated in several series in which the authors indicated this access with a variable frequency between 21.5 and $66.5 \%$ when the diagnosis occurred later than $24 h^{1,20,24,26}$.

Although in this study the transmediastinal via was preferred in most cases, possibly three of them with pleural infection may have been underestimated, since they evolved with loculated pleural effusion, empyema and trapped lung. Such cases required pleuroscopy, eventually a better drainage through thoracotomy and even pulmonary decortication. It is not known whether these patients would have developed the complications observed if they had been submitted to a transthoracic surgery from the beginning. All three cases had the time interval between perforation and surgery of less than $24 \mathrm{~h}$.

Regarding the reconstruction of the digestive tract, some authors support the need of a second surgical procedure, mainly because the patients are usually critically ill due to infection and therefore, surgery should be abbreviated. This was well demonstrated in the study of Salo et $\mathrm{al}^{24}$, in which 15 patients underwent reconstruction with gastric transposition between three to six months after urgency esophagectomy, with 
a mortality rate of $13.3 \%$. However, other authors indicate this option only when therapy is instituted after $72 \mathrm{~h}$, as the series of Stirling \& Orringer ${ }^{20}$ and Altorjay et $\mathrm{al}^{1}$, in which patients underwent reconstruction in a second surgical procedure in only $20.8 \%$ and $15.9 \%$ of the cases, respectively. Gupta \& $\operatorname{Kaman}^{14}$ encourage reconstructive surgery in the same surgical period, regardless of the time of diagnosis or severity of the infection, as demonstrated in their series of 33 patients. The authors of this paper also prefer to combine reconstruction in the same surgery as long as the diagnosis and therapy are carried out early and the patient has no obvious infectious process. However, only three patients in this study met these criteria, when esophagectomy along with gastric transposition was performed within one to six hours after perforation, and whether by clinical evaluation or imaging tests it was confirmed that there was no evidence of infection.

Despite the value of the urgent esophagectomy, it is not a procedure exempt from serious complications. Moreover, most patients have sepsis criteria on admission, which predisposes a higher morbidity from $25-64.5 \%$, as reported in several studies $20,22,24,26$. The difference in these rates is most often related to the time interval between perforation and esophageal resection. Periods longer than $24 \mathrm{~h}$ have greater morbidity and mortality rates of up to $14 \%$ due to multiple organ insufficiency secondary to sepsis ${ }^{19,20,24,25}$. This was very evident in this series, in which 11 patients who underwent esophagectomy in the first $12 \mathrm{~h}$ had absolutely no complications. The 13 patients who underwent surgery between $12-48 \mathrm{~h}$, had one or more complications but no deaths. Nevertheless, the seven patients operated after $48 \mathrm{~h}$ had a fatal outcome.

Even considering the frequently late diagnosis and the high mortality rates, some authors have demonstrated the validity of esophagectomy, as the indication rates began to rise, reaching between $50-64.5 \% 1,13,14,20$.

Currently, minimally invasive techniques using endoscopic stents for esophageal repair demonstrated good results ${ }^{6}$. A recent meta-analysis showed a slight reduction in the overall mortality with the use of endoscopic techniques, but studies may be biased by patient selection and scarcity of published data ${ }^{7}$. In developing countries, the major challenge is the lack of infra-structure in most hospitals with very few trained professionals. Further studies should compare the results of these new therapeutic modalities.

\section{CONCLUSION}

Esophageal perforation is a severe event with a difficult therapeutic standardization. The challenge is due to its multifactorial etiology and the fact that the majority of patients is admitted with sepsis, a situation which can be aggravated with the delay between the diagnosis of esophageal injury and the initiation of treatment. Even with its undeniable morbidity, urgency esophagectomy in cases of perforation has its validity, particularly in patients with obstructive lesions of the esophagus.

\section{REFERENCES}

1. Altorjay A, Kiss J, Vörös A, Szirányi E. The role of esophagectomy in the management of esophageal perforations. Ann Thorac Surg. 1998; 65(5):1433-6.

2. Aquino JLB, Camargo JGT, Tafuri MJ. Trauma de esôfago: análise retrospectiva de 113 casos. In Congresso Brasileiro de Cirurgia 2005, Rio de Janeiro, RJ, Anais
3. Asensio JA, Berne J, Demetriades D et al. Penetrating esophageal injuries: time interval of safety for preoperative evaluation -- how long is safe? J Trauma. 1997; 43(2):319-24

4. Asensio JA, Chahwan S, Forno W et al. Penetrating esophageal Injuries: multicenter study of the American Association for the Surgery of Trauma. J Trauma. 2001; 50(2):289-96.

5. Attar S, Hankins JR, Suter CM, Coughlin TR, Sequeira A, McLaughlin JS. Esophageal perforation: a therapeutic challenge. Ann Thorac Surg. 1990; 50(1):45-51.

6. Ben-David K, Behrns K, Hochwald S et al. Esophageal perforation management using a multidisciplinary minimally invasive treatment algorithm. J Am Coll Surg. 2014; 218(4):768-74.

7. Biancari F, D'Andrea V, Paone R et al. Current treatment and outcome of esophageal perforations in adults: systematic review and metaanalysis of 75 studies. World J Surg. 2013; 37(5):1051-9.

8. Elebute EA, Stoner HB. The grading of sepsis. Br J Surg. 1983; 70(1):29-31.

9. Eroglu A, Can Kürkçüogu I, Karaoganogu N, Tekinbas C, Yimaz O, Basog M. Esophageal perforation: the importance of early diagnosis and primary repair. Dis Esophagus. 2004; 17(1):91-4.

10. Eroglu A, Turkyilmaz A, Aydin Y, Yekeler E, Karaoglanoglu N. Current management of esophageal perforation: 20 years experience. Dis Esophagus. 2009; 22(4):374-80.

11. Finley RJ, Pearson FG, Weisel RD, Todd TR, Ilves R, Cooper J. The management of nonmalignant intrathoracic esophageal perforations. Ann Thorac Surg. 1980; 30(6):575-83.

12. Fraga GP, Mantovani M, Andreollo NA, Pellizer A, Lourenço JLG, Dorsa TK. Perfurações traumáticas do esôfago. Arq Bras Cir Dig. 2004; 17(4):155-62.

13.GuptaNM.Emergencytranshiataloesophagectomyforinstrumental perforation of an obstructed thoracic oesophagus. Br J Surg. 1996; 83(7):1007-9.

14. Gupta NM, Kaman L. Personal management of 57 consecutive patients with esophageal perforation. Am J Surg. 2004; 187(1):5863.

15. Hendren $\mathrm{WH}$, Henderson BM. Immediate esophagectomy for instrumental perforation of the thoracic esophagus. Ann Surg. 1968; 168(6):997-1003.

16. Huber-Lang M, Henne-Bruns D, Schmitz B, Wuerl P. Esophageal perforation: principles of diagnosis and surgical management. Surg Today. 2006; 36(4):332-340.

17. Imre J. Plastic tube prosthesis for the surgical treatment of perforations in esophageal strictures. Ann Thorac Surg. 1973; 15(3):275-80.

18. Jones WG 2nd, Ginsberg RJ. Esophageal perforation: a continuing challenge. Ann Thorac Surg. 1992; 53(3):534-43.

19. Kiernan PD, Sheridan MJ, Hettrick V, Vaughan B, Graling P. Thoracic esophageal perforation: one surgeon's experience. Dis Esophagus. 2006; 19(1):24-30.

20. Orringer MB, Stirling MC. Esophagectomy for esophageal disruption. Ann Thorac Surg. 1990; 49(1):35-43.

21. Pinotti HW. Acesso transmediastinal ao esôfago por frenotomia mediana. Rev Ass Med Bras. 1976; 16(1):15-9.

22. Port JL, Kent MS, Korst RJ, Bacchetta M, Altorki NK. Thoracic Esophageal perforations: a decade of experience. Ann Thorac Surg. 2003; 75(4):1071-4.

23. Reeder LB, DeFilippi VJ, Ferguson MK. Current results of therapy for esophageal perforation. Am J Surg. 1995; 169(6):615-7.

24. Salo JA, Isolauri JO, Heikkilä LJ et al. Management of delayed esophageal perforation with mediastinal sepsis. Esophagectomy or primary repair? J Thorac Cardiovasc Surg. 1993; 106(6):1088-91.

25. Shaker H, Elsayed H, Whittle I, Hussein S, Shackcloth M. The influence of the 'golden 24-h rule' on the prognosis of oesophageal perforation in the modern era. Eur J Cardiothorac Surg. 2010; 38(2):216-22

26. Vallböhmer $D$, Hölscher $A H$, Hölscher $M$ et al. Options in the management of esophageal perforation: analysis over a 12 -year period. Dis Esophagus. 2010; 23(3):185-90.

27. White RK, Morris DM. Diagnosis and management of esophageal perforations. Am Surg. 1992; 58(2):112-9 